\title{
COMBAT STIFFNESS OF THE LAUNCHER PLATFORM
}

\author{
Miloš S. Lazarević \\ University of Kragujevac, Faculty of Engineering, Kragujevac, \\ Republic of Serbia, \\ e-mail: laky_boy_kg@hotmail.com, \\ ORCID iD:Dhttp://orcid.org/0000-0002-5441-4482
}

http://dx.doi.org/10.5937/vojtehg65-14716

FIELD: Mechanical Engineering

ARTICLE TYPE: Original Scientific Paper

ARTICLE LANGUAGE: English

Summary:

Possible loads on a multiple rocket launcher have been systemized and analyzed. Based on the analysis of loads, a mathematical-mechanical model has been made to describe the stability of a MLR hit by a high explosive-fragmentation projectile (HE-FRAG) in a close range. The results give the dependency of the launcher stability on explosion proximity, its typeand the explosive charge mass. The stability limit is determined by the force that can turn over the laucher and compromise the stability of projectiles inside. To simplify the given model, the kinetic energy is calculated for a projectile fragment that hits the launcher.

Key words: load, explosion effect, surface explosion, above ground explosion, conditions, critical pressure, critical distance, overturn, stability, kinetic energy.

\section{Introduction}

In order to meet stringent tactical-technical requirements regarding mobility, efficiency, range, up-to-date targets and stiffness, a multiple launching rocket system construction needs to be specific in comparison to other assets of support (Kari, 2007, p.9). Looking at it generally, a multiple launching rocket system is under the following loads (Milinović, 2002, p.155):

Static loads (mechanical):

- the effects of the vehicle weight and the launcher type.

Thermic loads:

- the effects from the combustion products during the launch on the launcher box; 
- the detonation products effects when a projectile explodes in the vicinity of the launcher.

Dynamic loads:

- dynamic loads during above ground and surface explosions in the close proximity;

- dynamic loads from the gases during a rocket launch;

- transport loads;

- wind blasts.

From all these loads, the most critical are the dynamic loads during above ground or surface explosions in the close proximity, so we will only take this group for a further analysis.

\section{Determining the maximum pressure of the blast wave on the launcher}

As a model for the blast wave pressure, we have accepted a cylindrical coordinate system with independent variables $\varphi$ and $\theta$ as shown in Figure1.

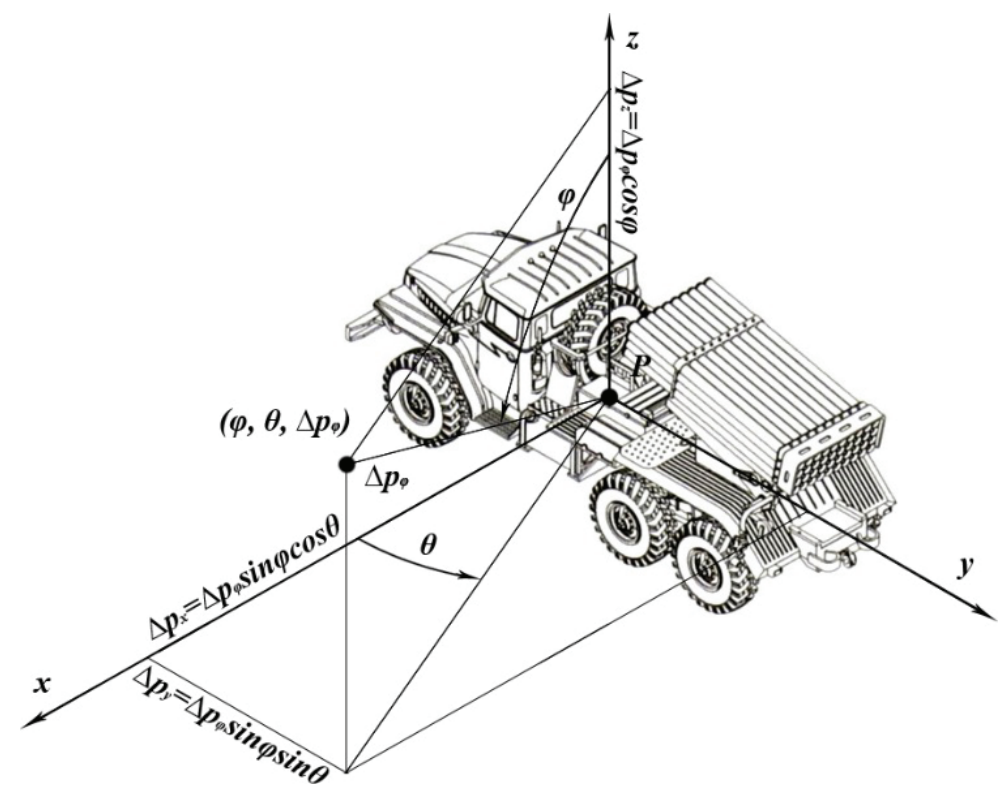

Figure 1 - Physical model for the directional effect of the blast wave on the launcher (Lazarević, 2017, p.11)

Puc. 1 - Физическое воздействие ударной волны на РСЗО (Lazarević, 2017, p.11) Слика 1 - Физички модел дејства ударног таласа на лансер (Lazarević, 2017, p.11) 
Figure 2 represents the basis of the mechanical-mathematical model of the stability of the launcher hit by the blast wave from an explosion. The end result is the maximum pressure of the blast wave during which the stability of the launcher will not be compromised.

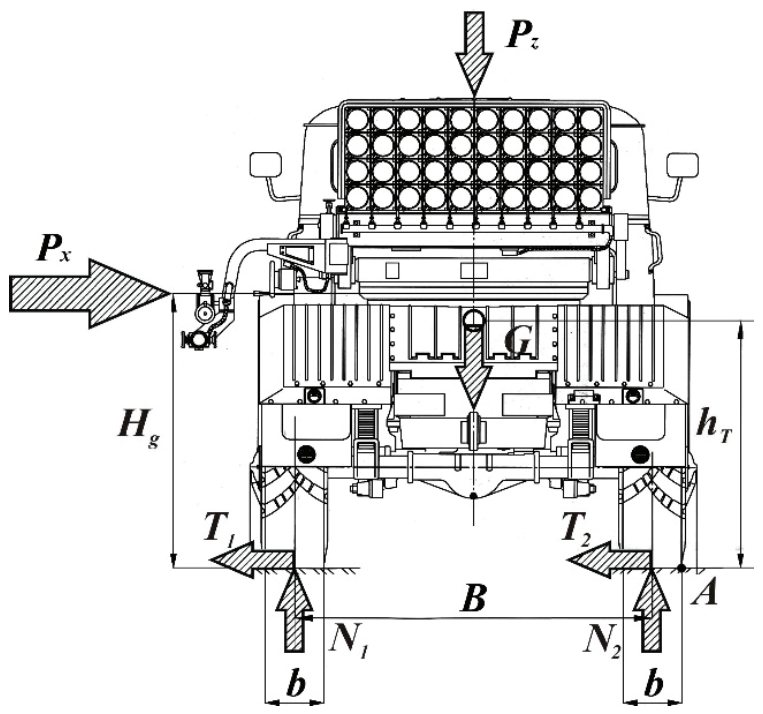

Figure 2 - Balance force of the launcher (Lazarević, 2017, p.20)

Pис. 2 - Равновесие сил РСЗО (Lazarević, 2017, p.20)

Слика 2 - Равнотежа сила самоходног лансера (Lazarević, 2017, p.20)

$\sum F_{x}=0 ; \sum F_{v}=0 ; \quad \sum M_{A}=0$

$P-\left(T_{1}+T_{2}=0\right)$

$f(Q+G)=T_{1}+T_{2}$

where:

$$
P_{x}=\Delta p \sin \varphi \cos \theta \cdot A_{L}=c_{x} \cdot \frac{2.5 \cdot \Delta p_{\varphi}{ }^{2}}{\Delta p_{\varphi}+709205} \sin \varphi \cos \theta \cdot A_{L} \quad-\text { the }
$$

resulting force caused by the explosion from the left side of the vehicle onto the side surface of the launcher $\mathrm{A}_{\mathrm{L}}$;

$P_{z}=\Delta p_{\varphi} \cdot A_{G}$ - the force of overpressure from the blast wave from the upper side of the vehicle on the upper surface of the launcher $A_{G}$;

$f$-adherence coefficient of the self propelled launcher when it is static or when it is on the move.

The average values of the coefficient are given in Table 1. 
Based on the balance (equation 1), it follows (Kari \& Milinović, 2008, p.36):

$$
c_{x} \cdot \frac{2.5 \cdot \Delta p_{\varphi}{ }^{2}}{\Delta p_{\varphi}+709205} \sin \varphi \cos \theta \cdot A_{L}=f \cdot\left(\Delta P_{\varphi} \cdot A_{G}+G\right)
$$

Table 1 - The average values for the adherence cofficient (Simić, 1988, p.104)

Таблица 1 - Средние значения коэффрициента сцепления (Simić, 1988, p.104)

Табела 1 - Просечне вредности коефицијента пријањања (Simić, 1988, p.104)

\begin{tabular}{|c|c|c|c|}
\hline \multirow{2}{*}{\multicolumn{2}{|c|}{ Types and conditions of the road }} & \multicolumn{2}{|c|}{ Adherence coefficient } \\
\hline & & \multirow{2}{*}{$\begin{array}{c}\text { Dry } \\
0.74 \\
0.68 \\
\end{array}$} & \multirow{2}{*}{$\begin{array}{l}\text { Wet } \\
0.71 \\
0.64 \\
\end{array}$} \\
\hline Concrete & $\begin{array}{l}2 \text { years old } \\
5 \text { years old, dirty }\end{array}$ & & \\
\hline Asphalt n & old, dirty & $\begin{array}{c}0.7-0.8 \\
-\end{array}$ & $\begin{array}{c}0.5-0.6 \\
0.25-0.45\end{array}$ \\
\hline \multicolumn{2}{|c|}{ Woodblocks } & $0.6-0.8$ & $0.3-0.5$ \\
\hline \multicolumn{2}{|r|}{$\begin{array}{l}\text { sand filling } \\
\text { asphalt filling }\end{array}$} & $\begin{array}{c}0.7-0.8 \\
0.82-0.89\end{array}$ & $\begin{array}{c}0.4-0.5 \\
0.60-0.65\end{array}$ \\
\hline \multicolumn{2}{|c|}{ Gravel or macadam } & $0.6-0.7$ & $0.3-0.5$ \\
\hline \multicolumn{2}{|l|}{ Slag } & $0.5-0.6$ & - \\
\hline \multicolumn{2}{|l|}{ Dirt road } & $0.50-0.65$ & $0.3-0.4$ \\
\hline \multicolumn{2}{|c|}{ Lawn25-30\%on the wet ground } & $0.20-0.30$ & - \\
\hline Snow & $\begin{array}{l}\text { powder } \\
\text { packed }\end{array}$ & $\begin{array}{l}0.20-0.40 \\
0.30-0.50\end{array}$ & \\
\hline $\begin{array}{l}\text { Ice, flat, g } \\
\text { (temperat }\end{array}$ & elow $\left.0^{\circ} \mathrm{C}\right)$ & $0.05-0.10$ & \\
\hline
\end{tabular}

On the basis of the moment equation (2), we get the condition for the overturning of the launcher onto its side surface during an above ground or surface explosion (Kari \& Milinović, 2008, p.37):

$\left[c_{x} \cdot \frac{2.5 \cdot \Delta p_{\varphi}{ }^{2}}{\Delta p_{\varphi}+709205} \sin \varphi \cos \theta \cdot A_{L}\right] \cdot H_{G}-\left(\Delta P_{\varphi} \cdot A_{G}+G\right) \cdot \frac{B+b}{2}=0$

The condition of a critical explosion distance that would impair the stability of the rocket inside the launch tube from the side is: 


$$
1.2 \cdot \frac{2.5 \cdot \Delta p_{\varphi}{ }^{2}}{\Delta p_{\varphi}+709205} \sin \varphi \cos \theta \cdot A_{L}-3 g T=0
$$

The approximate surfaces for the silhouette of the launcher (Figures 3 and 4), are calculatedfor the BM-21 Grad launcher on the basis of the dimensions given in the tactical-technical characteristics (Jovančić, 2014, pp.80-81). Based on them, the surface on which the overpressure of the blast wave acts has been determined.

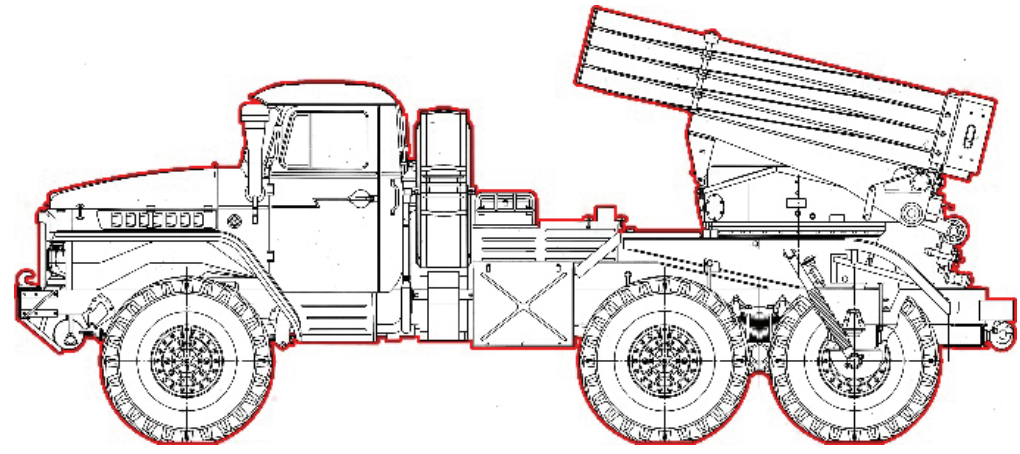

Figure 3 - The left side surface of the rocket launcher (Lazarević, 2017, p.22) Puc. 3 - РСЗО вид с боку (Lazarević, 2017, p.22)

Слика 3 - Површина бочне стране лансера ракета (Lazarević, 2017, p.22)

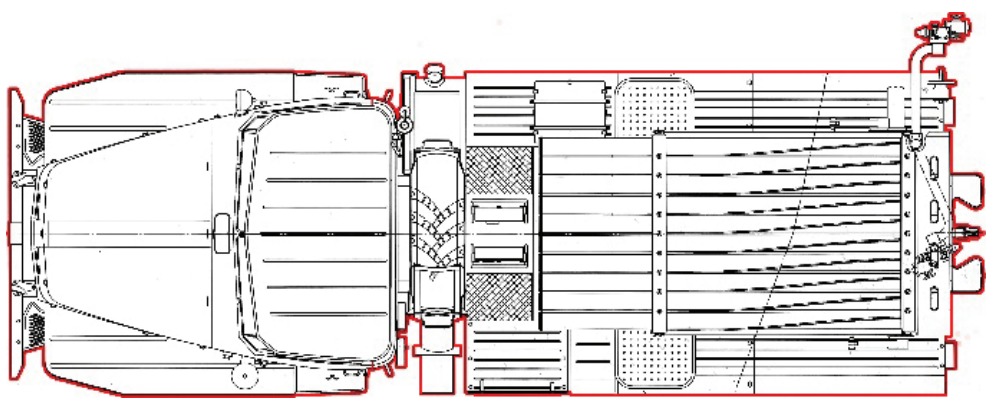

Figure 4 - The surface on the upper side of the rocket launcher (Lazarević, 2017, p.22) Puc. 4 - PCЗО вид с верху (Lazarević, 2017, p.22)

Слика 4 - Површина горње стране лансера ракета (Lazarević, 2017, p.22)

The obtained input data are shown in Table 2. 
Table 2 - Dimensional characteristics of the vehicle (Lazarević, 2017, p.23)

Таблица 2 - Размерные характеристики транспортного средства (Lazarević, 2017, p.23)

Табела 2 - Димензионе карактеристике возила (Lazarević, 2017, p.23)

\begin{tabular}{|c|c|c|}
\hline Weight of vehicle & $\mathrm{T}$ & $13700 \mathrm{~kg}$ \\
\hline The explosion effect angle & $\varphi$ & $20^{\circ} \div 90^{\circ}$ \\
\hline The explosion effect angle & $\theta$ & $-180^{\circ} \div 180^{\circ}$ \\
\hline The side surface of the vehicle & $\mathrm{A}_{\mathrm{L}}$ & $13.6 \mathrm{~m}^{2}$ \\
\hline The upper surface of the vehicle & $\mathrm{A}_{\mathrm{G}}$ & $16.8 \mathrm{~m}^{2}$ \\
\hline The rear surface of the vehicle & $\mathrm{A}_{\mathrm{z}}$ & $10.1 \mathrm{~m}^{2}$ \\
\hline The height of the action of the pressure center & $\mathrm{H}_{\mathrm{g}}$ & $1.58 \mathrm{~m}$ \\
\hline Vehicle center height & $\mathrm{h}_{\mathrm{T}}$ & $1.2 \mathrm{~m}$ \\
\hline Vehicle width & $\mathrm{B}$ & $2 \mathrm{~m}$ \\
\hline Tire width & $\mathrm{b}$ & $0.3 \mathrm{~m}$ \\
\hline
\end{tabular}

Since this is a squared equation, there are two solutions, out of which one is negative, so during our calculations we will only use the positive values of the blast wave pressure acting on the rocket launcher.

\section{Determining the explosion critical distance}

Most of the equations for the calculation of the blast wave and the impulse are based on the TNT equation. Thus, for explosives which are not TNT, it is preferable to know their equivalent mass.

The equivalent mass is calculated with the following equation (Mihelič, 2013, p.18):

$$
M_{T N T e}=\frac{E_{\text {deksp }}}{E_{d T N T}} M_{e k s p}
$$

where:

$M_{T N T E}$ - equivalent TNT mass [kg];

$E_{\text {deksp }}$ - the energy from the explosive detonation $[\mathrm{J} / \mathrm{kg}]$;

$E_{d T N T}$ - the energy from the TNT detonation $[\mathrm{J} / \mathrm{kg}]$;

$M_{\text {eksp }}$ - explosive mass [kg].

The calculation of the TNT equivalent is commonly based on the energy released during an explosion. The energy can be determined in many ways. Commonly used methods are based on the hydrodynamic or thermodynamic parameters.

In Table 3, the calculated TNT equivalents are shown for secondary explosives. The results are precise enough to be used for the calculation of the critical distance (Mihelič, 2013, pp.18-19). 
Table 3 - TNT equivalent for secondary explosives (Mihelič, 2013, p.20)

Таблица 3 - ТНТ эквивалент бризантных снарядов (Mihelič, 2013, p.20)

Табела 3 - TNT еквивалент за бризантне експлозиве (Mihelič, 2013, p.20)

\begin{tabular}{|c|c|c|c|}
\hline & \multicolumn{2}{|c|}{ TNT equivalent } & \multirow{2}{*}{$\begin{array}{c}\text { For the range of } \\
\text { pressures(MPa) }\end{array}$} \\
\hline & Pressure & Impulse & $0.035-0.350$ \\
\hline CompositionB & 1.11 & 0.98 & $0.035-0.350$ \\
\hline Composition C3 & 1.08 & 1.01 & $0.070-0.700$ \\
\hline Composition C4 & 1.37 & 1.19 & - \\
\hline Octol 72/25 & 1.06 & 1.06 & $0.035-0.700$ \\
\hline PETN & 1.27 & - & - \\
\hline RDX & 1.14 & 1.09 & $0.035-0.350$ \\
\hline RDX/TNT 60/40 & 1.14 & 1.09 & $0.021-0.140$ \\
\hline Tetryl & 1.07 & - & Standard \\
\hline TNT & 1.00 & 1.00 & $0.035-0.700$ \\
\hline Tritonal & 1.07 & 0.96 &
\end{tabular}

In order to make the calculation of equivalent explosive mass in ammunition easier, armies in the world maintain data bases with all necessary data on the amounts of explosives. Such a book is usually called "the yellow book".

The necessary data for the explosive mass equivalent to a $155 \mathrm{~mm}$ fragmentation shell is shown in Table 4.

Table 4 - Equivalent mass of explosive for the $155 \mathrm{~mm}$ HE shell (Lazarević, 2016, p.9)

Таблица 4 - Эквивалентная масса взрывчатых веществ фугасного снаряда, калибра 155 мм (Lazarević, 2016, p.9)

Табела 4 - Еквивалентна маса експлозива за ТФ гранату калибра $155 \mathrm{~mm}$ (Lazarević, 2016, p.9)

\begin{tabular}{|c|c|c|}
\hline TNT-RDX & TX & \\
\hline Mass of explosive charge & $\mathrm{M}_{\mathrm{eksp}}$ & $8.25 \mathrm{~kg}$ \\
\hline TNT Equivalent & $\mathrm{E}_{\text {deksp }} / \mathrm{E}_{\mathrm{dTNT}}$ & 1.14 \\
\hline Equivalent mass of explosive & $\mathrm{M}_{\text {TNTe }}$ & $9.405 \mathrm{~kg}$ \\
\hline
\end{tabular}

The main characteristics of the blast wave are the overpressure on its front and the time duration of the impulse whose value depends on the type of explosive used, the mass of the explosive and the distance from the explosion. On the basis of the experimental results for spherical blast waves resulting from the detonation of a certain amount of TNT, Sadovsky has suggested an empirical equation for the calculation of the blast wave 
overpressure in the wave front in the following form (Jeremić, 2002, p.369):

$$
\Delta p=k_{1} \frac{m_{e}^{\frac{1}{3}}}{r}+k_{2} \frac{m_{e}^{\frac{2}{3}}}{r}+k_{3} \frac{m_{e}}{r}[\text { bar }]
$$

where:

$m_{e}$ - explosive charge mass in $\mathrm{kg}$;

$r$ - distance from the center of the explosion in $\mathrm{m}$;

$k_{1}, k_{2}, k_{3}-$ empirical coefficients which depend on the explosive chargetype.

For TNT explosive and other types of medium-strength explosives, empirical coefficients for above ground explosions can be taken from Table 5:

Table 5-Coefficients $k_{1}, k_{2}, k_{3}$ depending on the type of explosion (Lazarević, 2017, p.13) Таблица 5-Коэфффициенты $k_{1}, k_{2}, k_{3}$, в зависимости от типа взрыва (Lazarević, 2017, p. 13) Табела 5- Коесрицијенти k $k_{1}$, k2, $k_{3}$ у зависности од типа експлозије (Lazarević, 2017, p.13)

\begin{tabular}{|c|c|c|}
\hline Type & Above ground explosion & Surface explosion \\
\hline$k_{1}$ & 0.85 & 1.1 \\
\hline$k_{2}$ & 3 & 4.3 \\
\hline$k_{3}$ & 8 & 14 \\
\hline
\end{tabular}

In the case of a surface explosion, the blast wave in the air spreads in the form of a half sphere (the volume is cut in half), so the overpressure in this case is bigger. That is when double mass (of the explosive charge mass) is usually used in equation (6).

Since during a surface explosion there is also a deformation of the ground, it is necessary to introduce the coefficient $\eta$ which depends on the type of ground, so the calculation of the explosive mass in equation (6) is equal to (Kari \& Milinović, 2008, p.33):

$$
m_{p}=2 \eta m_{e}
$$

By introducing the $k_{1}, k_{2}$, and $k_{3}$ coefficients of the equivalent explosive mass, the overturn pressure limit and the pressure which can compromise the stability of the launcher into equation 6 , it is possible to determine the critical distance for above ground explosions and surface explosions.

The solution of equation (6) is obtained by transforming it into the following form (http://forum.matemanija.com/viewtopic. php?f=2\&t=186, 2017): 


$$
y^{3}+p y+c x+d=0
$$

Where $p$ and $q$ have the following equality:

$$
\begin{aligned}
& p=-\frac{m^{\frac{2}{3}}\left(k_{1}^{2}+k_{2} 3 \Delta p_{\varphi}\right)}{3 \Delta p_{\varphi}^{2}} \\
& q=-\frac{m\left(27 k_{3} m \Delta p_{\varphi}^{2}+9 k_{1} k_{2} \Delta p_{\varphi}+2 k_{1}^{3}\right)}{27 \Delta p_{\varphi}^{2}}
\end{aligned}
$$

The calculation of the discriminant $D$ is done with the following form:

$$
D=\frac{q^{2}}{4}+\frac{p^{3}}{27}
$$

With the help of the Cardan equation, we get the solutions which go by $y$ :

$$
y_{1}=\sqrt[3]{-\frac{q}{2}+\sqrt{D}+\sqrt[3]{-\frac{q}{2}-\sqrt{D}}}
$$

So we can get the solution for the third level equation with the following form:

$$
r=y-\frac{k_{1} m^{\frac{2}{3}}}{3 \Delta p_{\varphi}}
$$

\section{Critical distance in the function of mass}

Under the assumption of the launcher overturning onto its side with the help of equation 3 , we get the maximum pressure of $\Delta p_{\varphi}=314654 \mathrm{~Pa}$. On the basis of that pressure, the diagram which shows the dependence between the critical distance and the explosive charge mass is made. The explosive mass is from 1 to $25 \mathrm{~kg}$. The obtained results are shown in Figure 5.

\section{The influence of fragmentation effects on the launcher}

During an explosion of a fragmentation projectile, besides the blast wave effect on the launcher, there is also the fragmentation effect. The fragmentation effect can affect the operation of the launcher system. The 
fragmentation effect is defined with the kinetic energy of a fragment, because of which a short calculationwill be given further on in the text.

The following fragmentation effect factorsdepend on the HE projectile construction (Stamatović, 1995, p.152):

- the number, individual weight and shape of fragments;

- the look and direction of the fragmentation dispersion form;

- the range and kinetic energy of fragments.

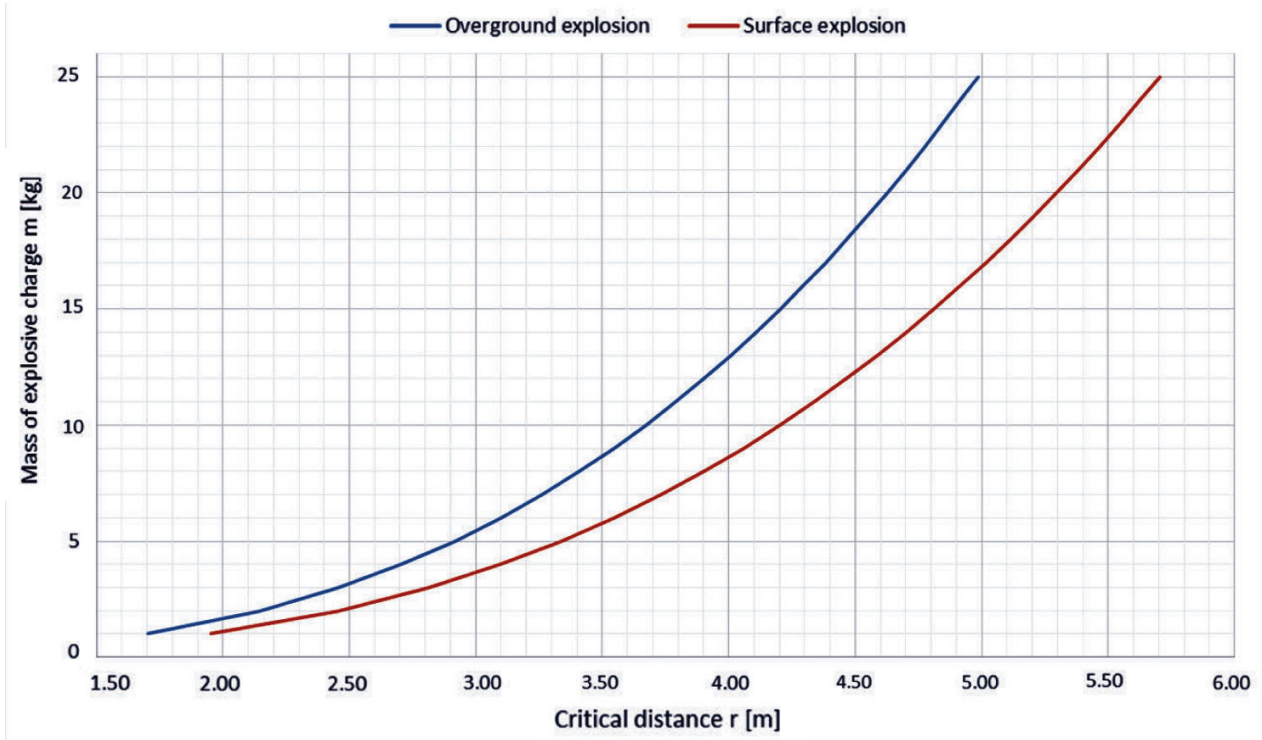

Figure 5 - The correlaction between the critical distance and the explosive chargemass for an above ground and surface explosion (Lazarević, 2017, p.30)

Puc. 5 - Зависимость критического расстояния от массы взрывного заряда, при воздушном и наземном взрыве (Lazarević, 2017, p.30)

Слика 5 - Зависност критичног растојања од масе експлозивног пуњења, при надземној и површинској експлозији (Lazarević, 2017, р.30)

\section{The number, individual mass and shape of fragments}

It is usual to evaluate the effect of a projectile on the basis of the following constructional parameters (Stamatović, 1995, p.152):

- relative projectile mass given in the following form $k_{p}=m / d^{3}$;

- relative mass of the explosive charge given in the following form $k_{e}=m_{e} / d^{3}$;

- charge coefficient $k=m_{e} / m \cdot 100(\%)$;

- projectile shell thickness $\delta$ given in calibers. 
If the parameters $k_{e}, k$ and $\delta$ change while caliber stays the same, we will prove that there are optimal values for these parameters with which we get the biggest number of fragments for the given explosive and projectile mass within the boundaries set beforehand (Table 6) (Stamatović, 1995, p.152).

Table 6 - The fragment mass for the $150 \mathrm{~mm}$ HE projectile (Stamatović, 1995, p.156)

Таблица 6 - Масса фррагментов осколочно-фугасного снаряда 155 мм (Stamatović, 1995, p.156)

Табела 6 - Маса парчади тренутнофугасног пројектила $155 \mathrm{~mm}$ (Stamatović, 1995, p.156)

\begin{tabular}{|c|c|c|c|c|c|}
\hline \multirow{2}{*}{ Case production } & \multirow{2}{*}{$\begin{array}{c}\text { Explosive } \\
\text { and mass } \\
(\mathrm{kg})\end{array}$} & $\begin{array}{c}\text { up to } \\
5 \mathrm{~g}\end{array}$ & $\begin{array}{c}\text { from } \\
1.5 \mathrm{to} \\
100 \mathrm{~g}\end{array}$ & $\begin{array}{c}\text { over } \\
100 \mathrm{~g}\end{array}$ & total \\
\cline { 3 - 6 } & & 185 & 251 & 14 & 327 \\
\hline Warm forging & $\mathrm{TX} / 8.25$ & 1969 & 1596 & 1 & 2263 \\
\hline Casting & $\mathrm{TX} / 8.25$ & \multicolumn{4}{|c}{ Number of fragments } \\
\hline
\end{tabular}

\section{The look and direction of the fragmentation dispersion} form

The usual shape of the inside of a projectile case (Figure 6) produces three beams during an explosion and the case destruction (Stamatović, 1995, pp.159-161):

- the beam formed from the front, oval part (around 10\%);

- the side beam of the case cylinder part (around 70\%);

- the rear beam formed from the case bottom (20\%). 


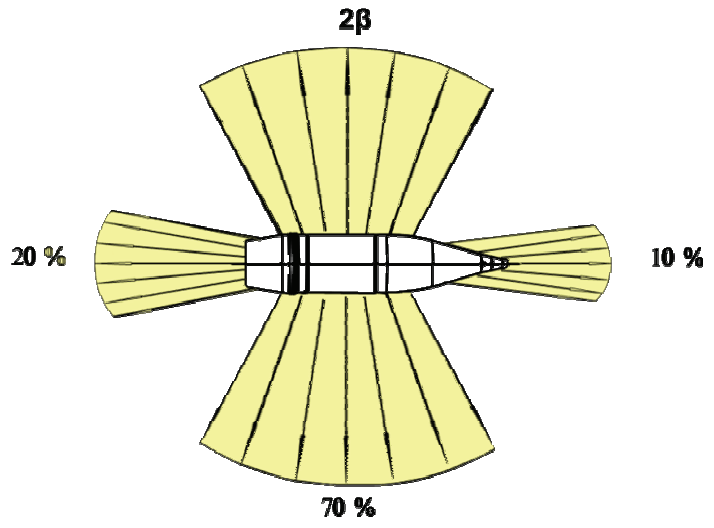

\section{The kinetic energy of fragments}

The velocity of fragments on the path $x$ decrease under the effect of wind resistance, which can be shown with the following equation (Stamatović, 1995, pp.169-172):

$$
F_{w}=\frac{1}{2} C_{x} S \rho_{w} V_{p}^{2}
$$

where:

$C_{x}$ - the coefficient of the aerodynamic resistance of the fragment of a mass of $m_{p}$;

$S$ - the biggest fragment cross section normal to the direction of movement;

$\rho_{w}$ - air density;

$V_{p}-$ fragmentation velocityat the end of the path $x$.

As $m_{p} V_{p} d V_{p}=F_{w} d x$, it is obtained: 


$$
d V_{p}=\frac{1}{2} C_{x} \frac{S}{m_{p}} V_{p} d x
$$

By adopting that the aerodynamic resistance coefficient $C_{x}=$ constfor supersonic speeds (for subsonic and transsonic speeds $C_{x}$ isnot constant) and with the integration of the last equation, we get:

$$
V_{p}=V_{p 0} e^{\frac{1}{2} C_{x} \frac{S}{m_{p}} \rho_{w} x}
$$

where:

$V_{p o}-$ resulting initial velocity of the fragment;

$V_{p}$ - the velocity of a fragment at the end of the path $x$.

The fragment with the mass $m_{p}$ possesses kinetic energy, if, when hitting the target, it has the velocity $V_{p m i n}$ obtained from the following relation:

$$
\frac{m_{p} V_{p \min }^{2}}{2}=E .
$$

The kinetic energy of the fragment with the mass $m_{p}$ is obtained if we put equation (17) into equation (16):

$$
E=\frac{m_{p}\left(V_{p o} e^{\frac{1}{2} C_{x} \frac{S}{m_{p}} \rho_{w} x}\right)^{2}}{2} .
$$

Taking into account the initial velocity, the mass, and the total number of fragments from Table 6 as well as the critical distance from equation (13), we get the total kinetic energy of the fragmentation effect on the launcher.

This model is a rough approximation of the real system. For more reliable models, we need to do experimental testing inside a ditch or depression and to determine the initial velocities of fragments using a radar, which is costly.

\section{Overview of the results}

\section{The condition for the overturn of the launcher}

Under the assumption that the equivalent explosive mass during an above ground detonation is constant, i.e. $9.405 \mathrm{~kg}$ (equation 5), the critical distances for overturning are calculated for the independent 
variables $\varphi$ and $\theta$, which are between $20-90$ and -180 to 180 , respectively. The obtained results are shown in Figure 7.

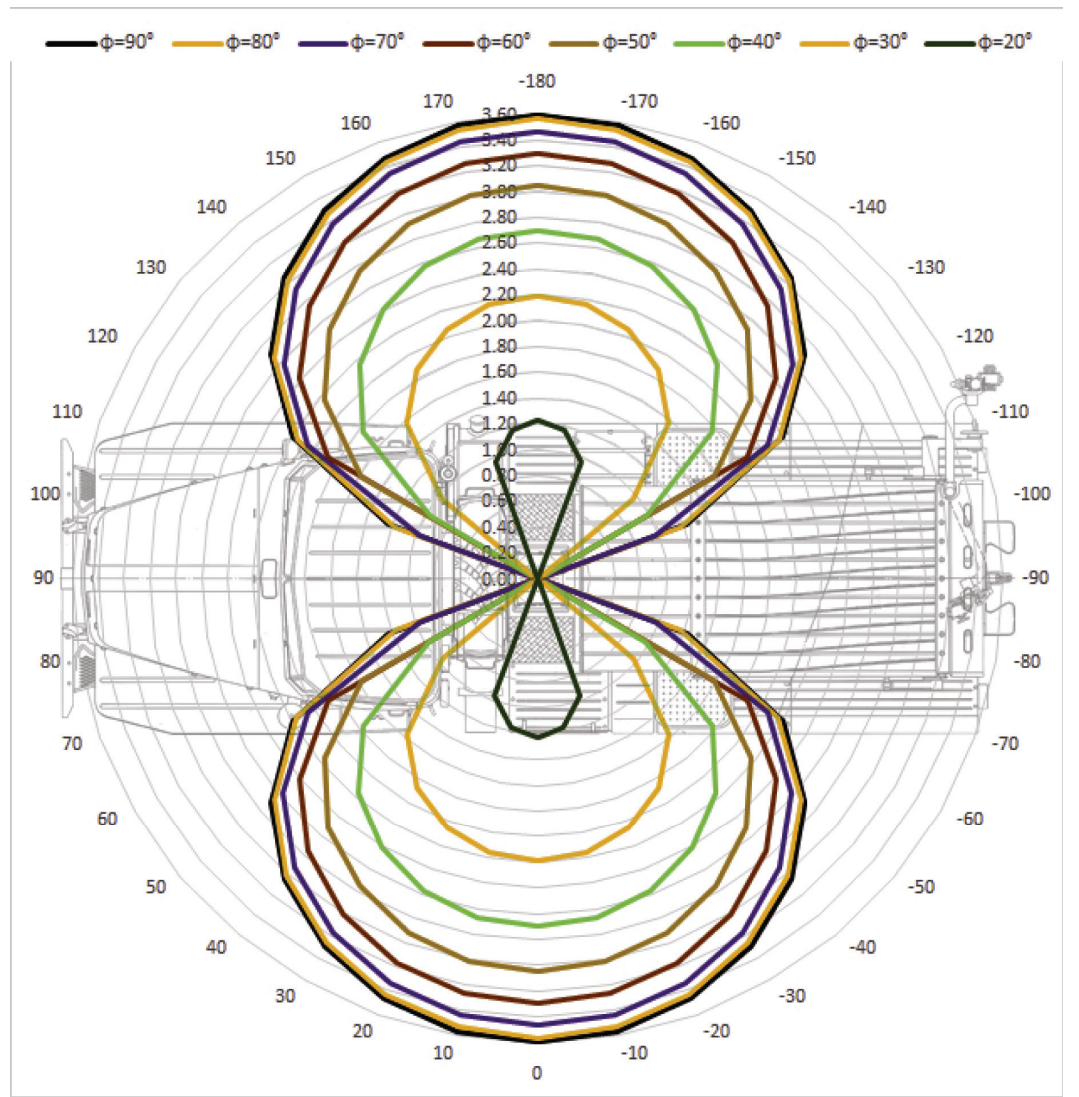

Figure 7 - Critical distance of launcher overturn in the function of $\varphi$ and $\theta$ for an above ground explosion (Lazarević, 2017, p.37)

Puc. 7 - Критическое расстояние опрокидывания РСЗО в фуннкции $\varphi$ и $\theta$ при воздушных взрывах (Lazarević, 2017, p.37)

Слика 7 - Критично растојање превртања лансера у функцији ч и $\theta$ при надземној експлозији (Lazarević, 2017, p.37)

Having in mind that the equivalent explosive mass during a surface explosion is two times bigger because of the half spherical spread of the blast wave, multiplied with the coefficient of the ground, we get an explosive mass of $14.108 \mathrm{~kg}$ (equation 7 ). On the basis of the mass and critical distance of overturn (equations 3 and 7 ), the critical distances of overturn have been calculated for the independent variables $\varphi$ and $\theta$, which are in the range between $90-20$ and -70 to 70 , respectively. The obtained results are shown in Figure 8. 


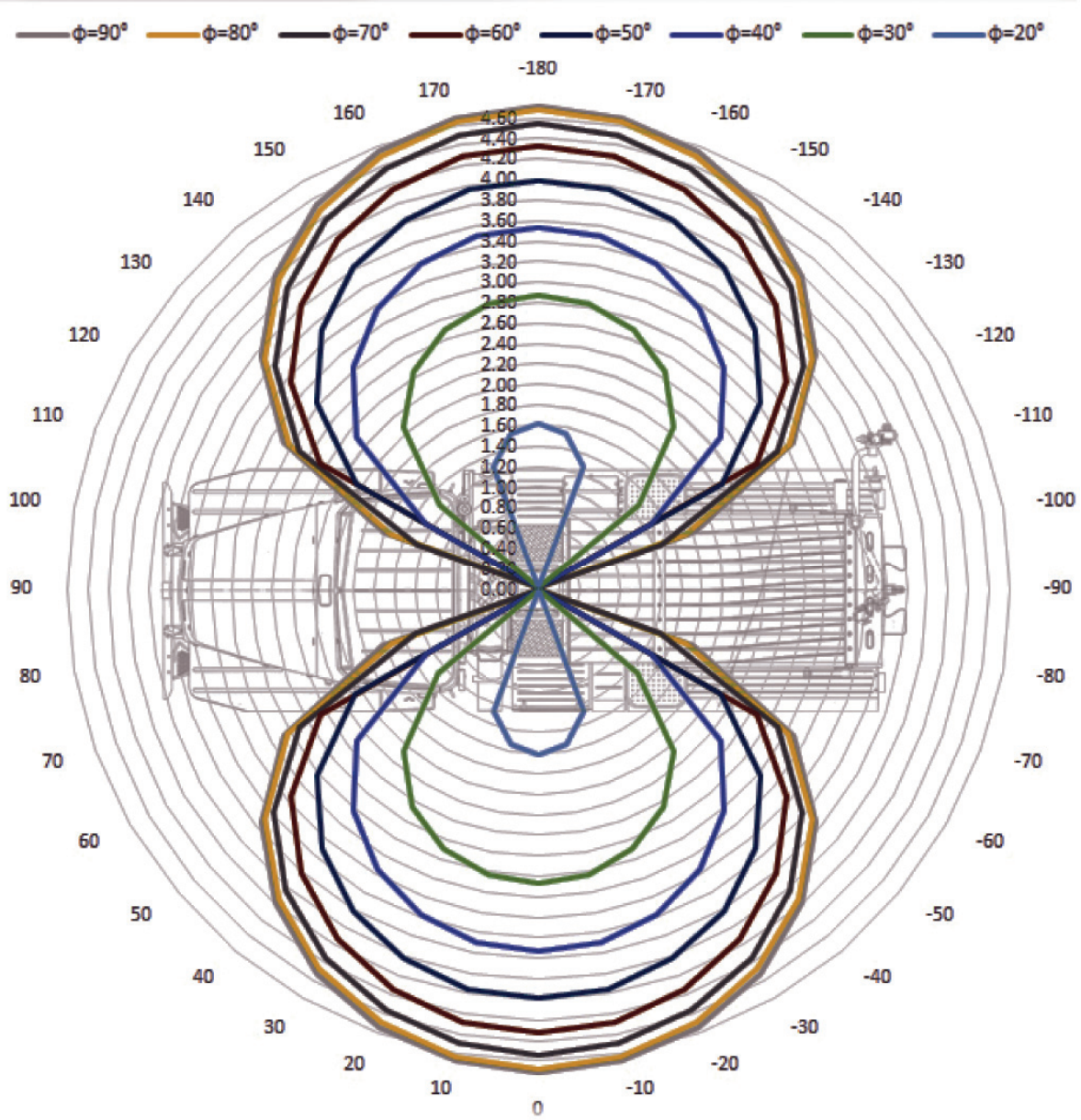

Figure 8 - Critical distance of launcher overturn in the function of $\varphi$ and $\theta$ for a surface explosion (Lazarević, 2017, p.38)

Puc. 8 - Критическое расстояние опрокидывания $P$ РЗО в функции $\varphi$ и $\theta$ при наземных взрывах (Lazarević, 2017, p.38)

Слика 8 - Критично растојање превртања лансера у функцији $\varphi$ и $\theta$ при површинској експлозији (Lazarević, 2017, p.38)

The condition for compromising the stability of the projectile inside the launcher tube

With a process similar to the one for overturning during an above ground explosion, we calculated the critical distance of compromising the stability of a projectile inside the launcher. With equations (4) and (5), we 
get the critical distances for the independent variables $\varphi$ and $\theta$ which vary between 90 to 20 and -80 to 80 , respectively. The results are shown in Figure 9 .

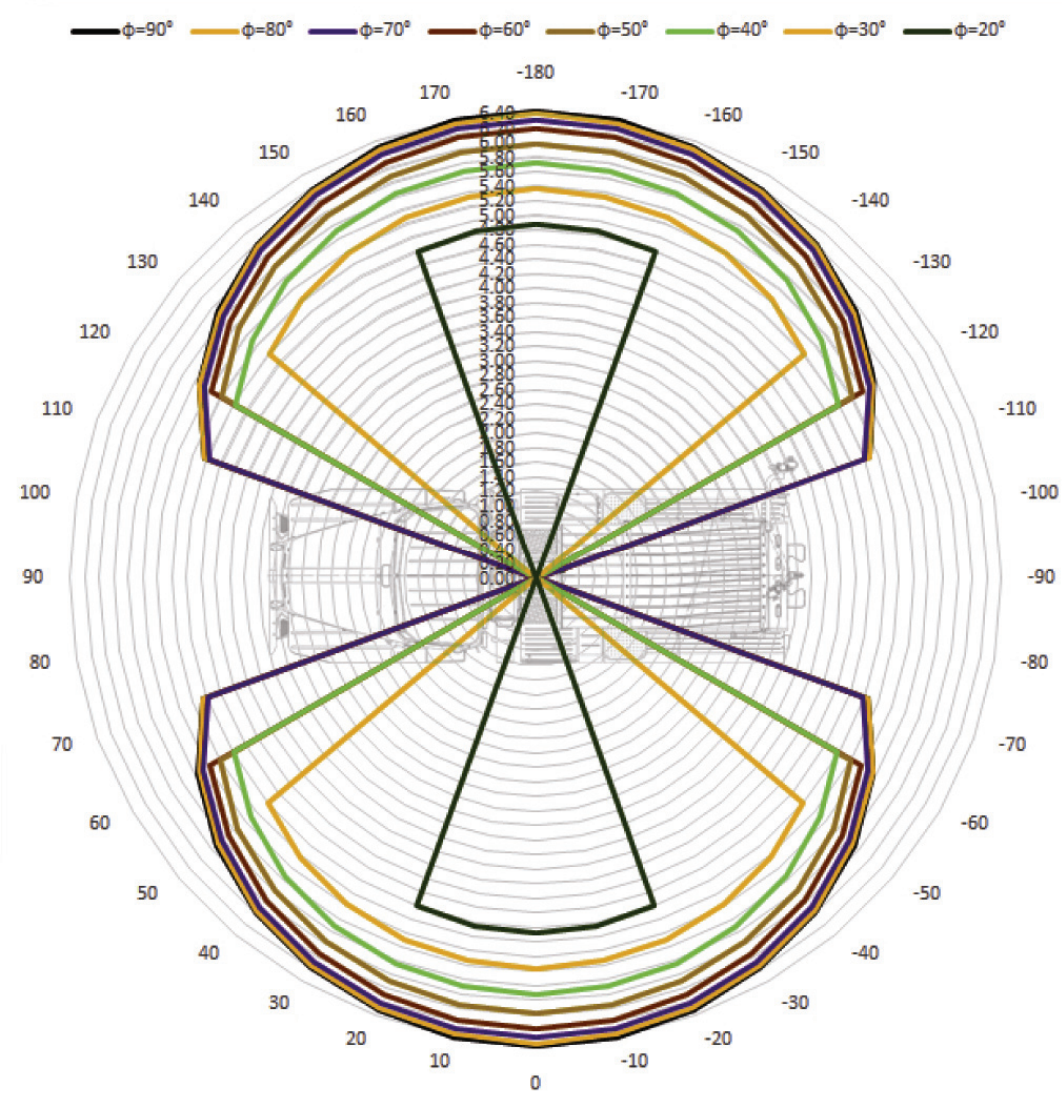

Figure 9 - Critical distance of compromising the projectile stability in the function of $\varphi$ and $\theta$ for an above ground explosion (Lazarević, 2017, p.39)

Puс. 9 - Критическое расстояние нарушения надежного удержания ракеты 8 функции ф и $\theta$ при воздушных взрывах (Lazarević, 2017, p.39)

Слика 9 - Критично растојање нарушавања поузданог држања ракете у фуннкцији ч и $\theta$ при надземној експлозији (Lazarević, 2017, p.39)

Having in mind that the equivalent explosive mass during a suface explosion is two times bigger because of the spread of the blast wave multiplied with the ground coefficient, we get an explosive mass of $14.108 \mathrm{~kg}$ (equation 7). 
For a surface explosion, the critical distances for compromising the projectile stability inside the launcher are calculated. With equations (4) and (7), we get the critical distances for the independent variables $\varphi$ and $\theta$, which are in the range from $90-20$ and -80 to 80 , respectively. The obtained results are shown in Figure 10.

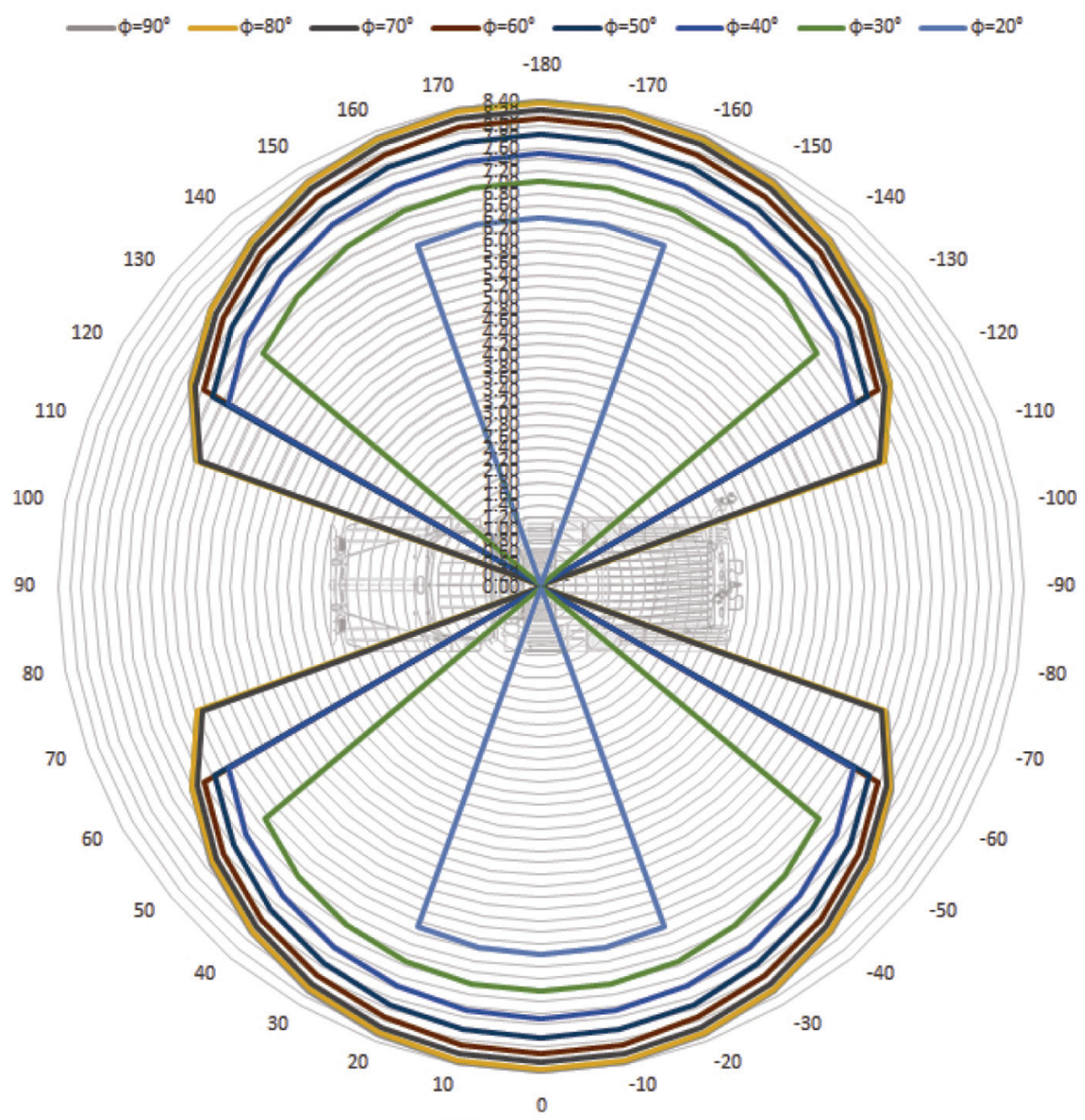

Figure 10 - Critical distance of compromising the projectile stability in the function of $\varphi$ and $\theta$ for a surface explosion (Lazarević, 2017, p.40)

Puc. 10 - Критическое расстояние нарушения надежного удержания ракеты 8 фоункции ф и $\theta$ при наземных взрывах (Lazarević, 2017, p.40)

Слика 10 - Критично растојање нарушавања поузданог држања ракете у фрункцији ч и $\theta$ при површинској експлозији (Lazarević, 2017, p.40) 


\section{Conclusion}

This mathematical model is a rough approximation of the real situation. To further develop the model, it is required to take into account the launcher suspensionand the launcher oscillations.

The analysis of the results has shown that during an above ground explosion the minimum distance to avoid the overturning of the BM21 Grad launcher iz 3.6 meters and it is 4.71 meters for a surface explosion (Figures 7 and 8).

As an addendum to the paper, the critical distance of the explosion during which the projectile stability would be compromised inside the launcher tube is also calculated. The stability of the projectile inside the launcher tube is defined with a maximum force of $3 \mathrm{~g}$.

The analysis of the results has shown that, in an above ground explosion, the minimum distance at which the projectile stability inside the launch tube would not be compromised is 6.42 meters and it is 8.41 meters when an explosion is a surface one (Figures 9 and 10).

A rough approximation of the fragmentation effect of the projectile on the launcher was done.

In order to get reliable data, it is necessary to carry out a series of tests run on a testing field on the given launcher.

\section{References}

http://forum.matemanija.com/viewtopic.php?f=2\&t=186. Accessed: 07.06.2017. Jeremić, R., 2002. Eksplozivni procesi. Belgrade: GŠ VJ, Uprava za ŠiO VA (in Serbian).

Jovančić, S., 2014. Samohodna višecevna raketna artiljerija. Belgrade: Vojnotehnički institut (in Serbian).

Kari, A. \& Milinović, M., 2008. Borbeno opterećenje višecevnog lansera usled dejstva udarnog talasa.Vojnotehnički glasnik/Military Technical Courier, 56(1), pp.3141. Available at: http://dx.doi.org/10.5937/vojtehg0801031K (in Serbian).

Kari, A., 2007. Poboljšanje performansi lansiranja i gađanja kod samohodnih višecevnih bacača raketa upotrebom posebnih mehanizama oslanjanja, Master thesis, University of Belgrade, Faculty of Mechanical Engineering (in Serbian).

Lazarević, M., 2016. Određivanje konstrukcionih parametara projektila $155 \mathrm{~mm}$ RM15P5, Seminar work, University of Kragujevac, Faculty of Engineering (in Serbian).

Lazarević, M., 2017. Borbena žilavost lansirnog sistema, Master Thesis, University of Kragujevac, Faculty of Engineering (in Serbian). 
Mihelič, B., 2013. Prilog formulama koje se koriste u upravljanju municijom. Kragujevac (in Serbian).

Milinović, M., 2002. Osnovi projekovanja raketa i lansera, poglavlja iz projektovanja lansera. Belgrade: University of Belgrade, Faculty of Mechanical Engineering (in Serbian).

Simić, D., 1988. Motorna vozila. Belgrade: IRO "Naučna knjiga" (in Serbian).

Stamatović, A., 1995. Konstruisanje projektila. Belgrade:"Ivexy" p.o. (in Serbian).

\section{БОЕВАЯ УСТОЙЧИВОСТЬ РСЗО}

Милош С. Лазаревич

Университет в г.Крагуевац, Факультет инженерных наук, г. Крагуевац,

Республика Сербия

ОБЛАСТЬ: машиностроение

ВИД СТАТЬИ: оригинальная научная статья

ЯЗЫК СТАТЬИ: английский

\section{Резюме:}

В данной работе приведены систематизация и анализ предельной нагрузки многоствольной ракетной пусковой установки. Исходя из анализа нагрузки, разработана механико-математическая модель устойчивости РСЗО, пораженной ОФ снарядом. На основании полученных результатов выявлена зависимость устойчивости пусковой установки от диапазона взрыва, типа взрыва и массы взрывного заряда. Главным условием боевой устойчивости РСЗО является разработка мер по предотвращению опрокидывания РСЗО и нарушения надежного держания ракеты в пусковой трубе. В иелях упрощения данной модели произведен расчет кинетической энергии воздействия осколков на ракетную пусковую установку.

Ключевые слова: нагрузка, действие взрыва, наземные взрывы, воздушные взрывы, условия, критическое давление, критическое расстояние, опрокидывание, устойчивость, кинетическая энергия.

\section{БОРБЕНА ЖИЛАВОСТ ЛАНСИРНОГ СИСТЕМА}

Милош С. Лазаревић

Универзитет у Крагујевцу, Факултет инжењерских наука, Крагујевац,

Република Србија

ОБЛАСТ: машинство

ВРСТА ЧЛАНКА: оригинални научни чланак

ЈЕЗИК ЧЛАНКА: енглески 


\section{Сажетак:}

У оквиру овог рада извршена је систематизација и анализа могућих оптерећења вишецевних лансера ракета. На основу анализе оптерећења израђен је математичко-механички модел стабилности вишецевног лансера ракета погођеног у непосредној близини тренутно-фругасним пројектилом. Добијени резултати указују на зависност стабилности лансера од удаљености експлозије, типа експлозије и масе експлозивног пуњења. Као гранични услов борбене жилавости лансера усвојен је услов почетног превртања лансера и нарушавања поузданог држања ракете у лансирној цеви. Ради упрошћавања приказаног модела извршен је прорачун кинетичке енергије ефикасног парчета које делује на лансер.

Кључне речи: оптерећење, дејство експлозије, површинска експлозија, надземна експлозија, услови, критичан притисак, критично растојање, превртање, стабилност, кинетичка енергија.

Paper received on / Дата получения работы / Датум пријема чланка: 02.08.2017.

Manuscript corrections submitted on / Дата получения исправленной версии работы / Датум достављања исправки рукописа: 12.08.2017.

Paper accepted for publishingon / Дата окончательного согласования работы / Датум коначног прихватања чланка за објављивање: 14.08.2017.

(c) 2017 The Author. Published by Vojnotehnički glasnik / Military Technical Courier (www.vtg.mod.gov.rs, втг.мо.упр.срб). This article is an open access article distributed under the terms and conditions of the Creative Commons Attribution license (http://creativecommons.org/licenses/by/3.0/rs/).

(c) 2017 Автор. Опубликовано в «Военно-технический вестник / Vojnotehničkiglasnik / Military Technical Courier» (www.vtg.mod.gov.rs, втг.мо.упр.срб). Данная статья в открытом доступе и распространяется в соответствии с лицензией «CreativeCommons» (http://creativecommons.org/licenses/by/3.0/rs/).

() 2017 Аутор. Објавио Војнотехнички гласник / Vojnotehnički glasnik / Military Technical Courier (www.vtg.mod.gov.rs, втг.мо.упр.срб). Ово је чланак отвореног приступа и дистрибуира се у складу са Creative Commons лиценцом (http://creativecommons.org/licenses/by/3.0/rs/). 